\title{
Assessment of Genetic Divergence by Using Multivariate Analysis for Physico Chemical Characters of Mango Table and Juicy Cultivars Grown in Telangana Region
}

B. Soujanya ${ }^{1}$, A. Kiran Kumar², S. Vanisri ${ }^{3}$, M. Sreedhar ${ }^{3}$,

P. Saidiah4, A. Bhagwan², G. Sathish ${ }^{4}$

10.18805/ajdfr.DR-1776

\begin{abstract}
Background: Mango (Mangifera indica L.) is well known for its diversity in Indian subcontinent and 1000 well known varieties are present all over the India among them 40 to 50 are having commercial importance. The present experiment was carried out at College of Horticulture, Rajendranagar during the year 2018-19 and 2019-20 to assess the genetic diversity in fifty mango cultivars using multivariate analysis over 25 physico-chemical characters

Methods: To assess the genetic diversity using $\mathrm{D}^{2}$ analysis and principal component analysis over 50 mango cultivars during 2 consecutive years.

Result: In the present investigation, the first seven principal components with eigen values more than one contributed $78.50 \%$ of cumulative variance among fifty genotypes. Fifty genotypes were grouped into eight clusters among them cluster I was the largest comprising of twenty-six genotypes. Average inter cluster distance ranged from 218.93 between cluster $V$ and VII to 1475.21 between cluster IV to VIII. Intra cluster distance ranged from 0.00 in cluster V, VI, VII and VIII to 280.69 in cluster III. The present results are most divergent for fruit weight, total phenols content, total flavonoid content, DA reading, fibre content, beta carotene, antioxidant activity, fruit length, fruit thickness. Selection of genotypes from clusters that are far genetically and had the maximum association of physico chemical characters to obtain superior segregants in the advanced generation to improve the quality of breeding in the future.
\end{abstract}

Key words: Cluster distance, Genetic diversity, Hybridization programme, Mango varieties, Principal component analysis, Physico chemical traits.

\section{INTRODUCTION}

Mango (Mnagifera indica L.) is a major fruit crop which is widely grown in tropical and subtropical countries of the world. It's related to Anacardiacea family in order Sapindales. India ranks first in production and consumption of mango in the world. In India, mango is cultivated in an area of 2.31 million ha with production of 22.35 million tonnes and 7.3 MT/ha productivity (NHB Data Base 2019-20). Major mango growing states are Uttar Pradesh, Andhra Pradesh, Odisha, Karnataka and Telangana.

In India, 1000 cultivars are well known for its commercial importance, Telangana state also has richest source of mango germplasm. Mango is having the chromosome number $2 n=40$ and $n=20$ and the genome size is $4.39 \times 108$ bp which is small in size but, morphologically distinguished among the cultivars of mango (Arumuganathan and Earle, 1991).

Genetic diversity analysis is generally used to identify diverse genotypes for hybridization purpose. Analysis of divergence can be performed by many statistical tools such as $\mathrm{D}^{2}$ Mahalanobis distance, Euclidean distance, average distance, etc. (Shirkhorshidi et al., 2015). Among the various methods identified to assess the genetic divergence in the varieties, the Mahalanobis $D^{2}$ (Mahalanobis, 1936) is reliable and most frequently used technique. $D^{2}$ analysis is a useful tool in quantifying the degree of divergence between biological population at genotypic level and to assess relative
${ }^{1}$ College of Horticulture, Sri Konda Laxman Telangana State Horticultural University, Rajendranagar-500 030, Telangana, India ${ }^{2}$ Sri Konda Laxman Telangana State Horticultural University, Mulugu, Siddipet-502 279, Telangana, India.

${ }^{3}$ Professor Jayashankar Telangana State Agricultural University, Rajendranagar-500 030, Telangana, India.

${ }^{4}$ College of Horticulture, Sri Konda Laxman Telangana State Horticultural University, Mojerla-509 219, Telangana, India.

Corresponding Author: B. Soujanya, College of Horticulture, Sri Konda Laxman Telangana State Horticultural University, Rajensranagar, Hyderabad-500 030, Telangana, India.

Email: bsoujanya129@gmail.com

How to cite this article: Soujanya, B., Kumar, A.K., Vanisri, S., Sreedhar, M., Saidiah, P., Bhagwan, A. and Sathish, G. (2022). Assessment of Genetic Divergence by Using Multivariate Analysis for Physico Chemical Characters of Mango Table and Juicy Cultivars Grown in Telangana Region. Asian Journal of Dairy and Food Research. DOI: 10.18805/ajdfr.DR-1776.

Submitted: 29-06-2021 Accepted: 27-11-2021 Online: 17-01-2022

contribution of different components to the total divergence, both at the inter- and intra-cluster levels by using the concept of statistical distance employing multivariate measurements and Principal Component analysis is used to identify traits that explain the phenotype variability best. 
There is a huge genetic resource exists in Telangana state. 477 mango cultivars established at Fruit Research Station (FRS), Sangareedy. Based on the strength of mango germplasm an attempt has been made to estimate genetic diversity among the mango table and juicy cultivars based on post-harvest physico chemical traits by using multivariate analysis. The present experiment was carried out with fifty mango table and juicy cultivars which are commercially importance of the state and an experiment entitled "Assessment of genetic divergence by using multivariate analysis for physico chemical characters of mango table and juicy cultivars grown in Telangana region".

\section{MATERIALS AND METHODS}

The experimental material comprised of fifty mango table and juicy cultivars which were collected from Fruit Research Station, Sangareddy by random sampling method. Present experiment was conducted on pre-established 15 years old and uniformly maintained mango orchard at FRS during the year 2018-2019 and 2019-2020 further analysis was carried out at College of Horticulture, Rajendranagar. Both table (36) and juicy (14) cultivars of mango used in the experiment.

\section{Selection and preparation of fruits}

Selected varieties were harvested based on their maturity standards and these fruits immediately transported to the laboratory and subjected to ripening with enripe and kept in low-cost ripening chamber. Fifty mango cultivars were analysed for all quantitative and qualitative traits and all these characters were subjected to completely randomized design with three replications, the level of significance was tested at $5 \%$ using $\mathrm{F}$ test (Panse and Sukhatme, 1989). The genetic divergence among the mango cultivars was worked out by using Mahalanobis's $D^{2}$ statistics (1936) and principal component analysis was done to identify traits that explain the phenotype variability best in SPSS version v.27.

\section{RESULTS AND DISCUSSION}

The results obtained from the principal component analysis was given in Table 1 and Fig $1 . D^{2}$ statistics (Toucher's method (Rao, 1952) based on $D^{2}$ values and distribution of genotypes in each cluster, Intra and inter cluster distances, cluster means and percent of contribution towards genetic diversity was accounted in Table 2 to 4 and Fig 2 and 3.

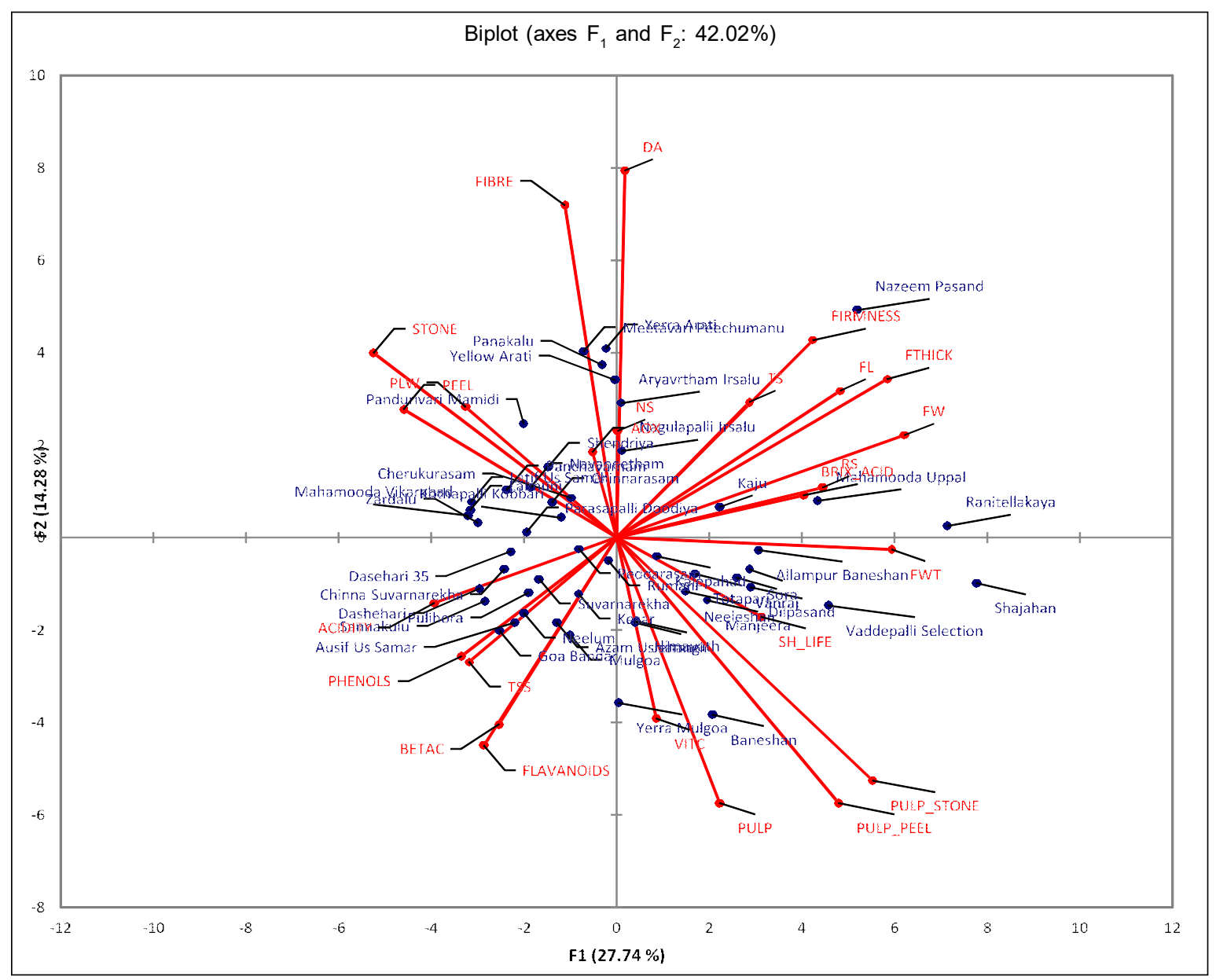

Fig 1: Biplot graphic with two principal components $\left(\mathrm{PC}_{1}\right.$ and $\left.\mathrm{PC}_{2}: 42.02 \%\right)$ for 25 quantitative and 25 traits of 50 mango cultivars grown in Telangana state. 
Assessment of Genetic Divergence by Using Multivariate Analysis for Physico Chemical Characters of Mango Table and Juicy...

Table 1: Principal component loadings of 25 quantitative and qualitative traits in 50 cultivars of mango grown in Telangana state.

\begin{tabular}{|c|c|c|c|c|c|c|c|c|}
\hline & \multirow[b]{2}{*}{$\mathrm{PC}_{1}$} & \multicolumn{7}{|c|}{ Principle component } \\
\hline & & $\mathrm{PC}_{2}$ & $\mathrm{PC}_{3}$ & $\mathrm{PC}_{4}$ & $\mathrm{PC}_{5}$ & $\mathrm{PC}_{6}$ & $\mathrm{PC}_{7}$ & $\mathrm{PC}_{8}$ \\
\hline Eigenvalue & 6.9348 & 3.5711 & 2.2479 & 2.1482 & 1.3804 & 1.3284 & 1.0686 & 0.9464 \\
\hline Variability (\%) & 27.7391 & 14.2845 & 8.9915 & 8.5926 & 5.5217 & 5.3135 & 4.2744 & 3.7857 \\
\hline Cumulative $\%$ & 27.7391 & 42.0236 & 51.0151 & 59.6077 & 65.1294 & 70.4429 & 74.7173 & 78.5030 \\
\hline Trait & & \multicolumn{7}{|c|}{ Factor loadings } \\
\hline & $\mathrm{F}_{1}$ & $\mathrm{~F}_{2}$ & $\mathrm{~F}_{3}$ & $\mathrm{~F}_{4}$ & $\mathrm{~F}_{5}$ & $\mathrm{~F}_{6}$ & $\mathrm{~F}_{7}$ & $\mathrm{~F}_{8}$ \\
\hline PLW \% & -0.443 & 0.276 & -0.028 & -0.380 & -0.021 & -0.063 & 0.499 & -0.226 \\
\hline Fruit length $(\mathrm{cm})$ & 0.657 & 0.310 & 0.031 & -0.157 & -0.069 & 0.100 & 0.041 & -0.026 \\
\hline Fruit width $(\mathrm{cm})$ & 0.846 & 0.216 & 0.090 & 0.045 & 0.124 & -0.096 & 0.068 & 0.320 \\
\hline Fruit thickness $(\mathrm{cm})$ & 0.795 & 0.335 & 0.035 & 0.115 & -0.028 & -0.147 & 0.039 & 0.237 \\
\hline Fruit weight (g) & 0.808 & -0.025 & 0.331 & -0.173 & 0.068 & -0.008 & 0.066 & 0.105 \\
\hline Peel \% & -0.625 & 0.271 & 0.145 & 0.269 & 0.232 & -0.235 & 0.189 & 0.102 \\
\hline Pulp \% & 0.303 & -0.560 & 0.500 & 0.029 & 0.302 & -0.062 & 0.122 & -0.200 \\
\hline Stone \% & -0.713 & 0.389 & -0.015 & 0.217 & 0.159 & -0.219 & 0.183 & 0.026 \\
\hline Pulp to peel ratio & 0.652 & -0.560 & 0.007 & -0.093 & 0.041 & 0.121 & 0.039 & -0.257 \\
\hline Pulp to stone ratio & 0.752 & -0.513 & 0.196 & 0.022 & 0.088 & 0.119 & -0.042 & -0.017 \\
\hline Shelf life (Days) & 0.424 & -0.167 & -0.411 & 0.295 & -0.187 & -0.263 & -0.086 & -0.070 \\
\hline Firmness $\left(\mathrm{kg} / \mathrm{cm}^{2}\right)$ & 0.577 & 0.417 & -0.241 & 0.302 & -0.026 & -0.211 & 0.115 & -0.174 \\
\hline DA reading & 0.024 & 0.775 & 0.078 & -0.101 & -0.109 & 0.210 & -0.025 & -0.199 \\
\hline TSS ${ }^{\circ} B r i x$ & -0.433 & -0.263 & 0.030 & 0.136 & 0.577 & 0.369 & 0.083 & 0.005 \\
\hline Acidity \% & -0.535 & -0.138 & 0.671 & -0.180 & -0.232 & -0.142 & -0.033 & 0.211 \\
\hline Vitamin C $(\mathrm{mg} / 100 \mathrm{~g})$ & 0.116 & -0.382 & 0.155 & -0.243 & -0.400 & 0.215 & 0.495 & -0.220 \\
\hline Brix: acid & 0.549 & 0.089 & -0.624 & 0.238 & 0.349 & 0.179 & 0.152 & -0.174 \\
\hline Total sugars \% & 0.390 & 0.286 & 0.362 & 0.608 & -0.317 & 0.229 & 0.075 & -0.028 \\
\hline Reducing sugars \% & 0.605 & 0.105 & -0.177 & -0.200 & -0.163 & 0.147 & 0.261 & 0.397 \\
\hline Non reducing sugars \% & 0.004 & 0.225 & 0.477 & 0.720 & -0.211 & 0.156 & -0.125 & -0.263 \\
\hline $\begin{array}{l}\text { Total phenols content } \\
\text { (mg of gallic acid } / 100 \mathrm{~g} \text { ) }\end{array}$ & -0.456 & -0.251 & -0.293 & 0.256 & -0.280 & 0.332 & 0.329 & 0.302 \\
\hline $\begin{array}{l}\text { Total flavonoid content } \\
\text { (mg QE/100g) }\end{array}$ & -0.389 & -0.439 & -0.145 & 0.448 & -0.009 & 0.408 & -0.073 & 0.240 \\
\hline Beta carotene $(\mathrm{mg} / 100 \mathrm{~g})$ & -0.344 & -0.394 & -0.443 & 0.063 & -0.422 & -0.207 & -0.067 & -0.163 \\
\hline Antioxidant activity $(\mu \mathrm{g} / 100 \mathrm{~g})$ & -0.070 & 0.180 & -0.155 & -0.468 & -0.149 & 0.352 & -0.464 & -0.022 \\
\hline Fibre content $(g / 100)$ & -0.152 & 0.702 & 0.053 & -0.181 & 0.093 & 0.463 & 0.010 & -0.079 \\
\hline
\end{tabular}

Table 2: Clustering pattern of 50 mango genotypes into different clusters based on post-harvest traits by $D^{2}$ analysis.

\begin{tabular}{|c|c|c|}
\hline Clusters & No. of genotypes & Name of genotype \\
\hline I & 26 & $\begin{array}{l}\text { Dashehari-35, Dashehari, Zardalu, Neelum, Asif Us Samar, Mahamooda Vikarabad, Goa Bandar, } \\
\text { Sannakulu, Baneshan, Suvarnarekha, Latif Us Samar, Lalmuni, Chinna Suvarnarekha, Chinna Rasam, } \\
\text { Kothapalli Kobbari, Mulgoa, Jehangir, Parasapalli Doodiya, Himayath, Dilpasand, Majeera, Kesar, } \\
\text { Rumani, Azam Us Samar, Panchavarnam, Cheruku Rasam }\end{array}$ \\
\hline II & 9 & $\begin{array}{l}\text { Meetavari Peechumanu, Panakalu, Aryavartham Irsalu, Pandurivari Mamidi, Yerra Arati, Yellow Arati, } \\
\text { Navaneetham, Pedda Rasam, Mahamooda Uppal }\end{array}$ \\
\hline III & 9 & $\begin{array}{l}\text { Ranitellakaya, Shajahan, Nazeem Pasand, Vaddepalli Selection, Neeleshan, Allampur Baneshan, } \\
\text { Kalepahad, Totapari, Nagualapalli Irsalu }\end{array}$ \\
\hline IV & 2 & Pulihora, Yerra Mulgoa, \\
\hline V & 1 & Vanraj \\
\hline VI & 1 & Shendriya \\
\hline VII & 1 & Kaju \\
\hline VIII & 1 & Sora \\
\hline
\end{tabular}




\section{Principal component analysis (PCA)}

PCA analysis based on correlation matrix for physico chemical characters studied in fifty mango cultivars includes principal components, eigen values, per cent of variability and cumulative per cent of variability and also factor loading values of different traits for the respective principal components are furnished in Table 1 and Fig 1. The principal components with eigen values above one was considered as significant and less than one was considered as nonsignificant as per the procedure.

As per the PCA analysis, the first seven principal components with eigen values more than one are explained $74.71 \%$ of the total variance among the fifty mango cultivars. The first principal component (PCI) accounted for $27.73 \%$ of total variation, included fruit length $(\mathrm{cm})$, fruit width $(\mathrm{cm})$, fruit thickness $(\mathrm{cm})$, fruit weight $(\mathrm{g})$, pulp per cent, pulp to peel ratio, pulp to stone ratio, shelf life, brix acid ratio, total sugars (\%), reducing sugars (\%) showed positive loadings. The second principal component was explained $14.28 \%$ total variation and was positively associated with fruit length $(\mathrm{cm})$, fruit thickness $(\mathrm{cm})$, stone per cent, firmness $\left(\mathrm{kg} / \mathrm{cm}^{2}\right)$, DA reading, fibre content $(\mathrm{g} / 100 \mathrm{~g})$. The third principal component accounted for $8.99 \%$ variability and showed high positive correlation for acidity (\%), pulp (\%), non reducing sugars (\%), total sugars (\%), fruit weight $(\mathrm{g})$. The fourth principal component explained the variability $8.59 \%$ and positively associated with firmness $\left(\mathrm{kg} / \mathrm{cm}^{2}\right)$, total sugars (\%), non reducing sugars, total flavonoid content (mg QE/

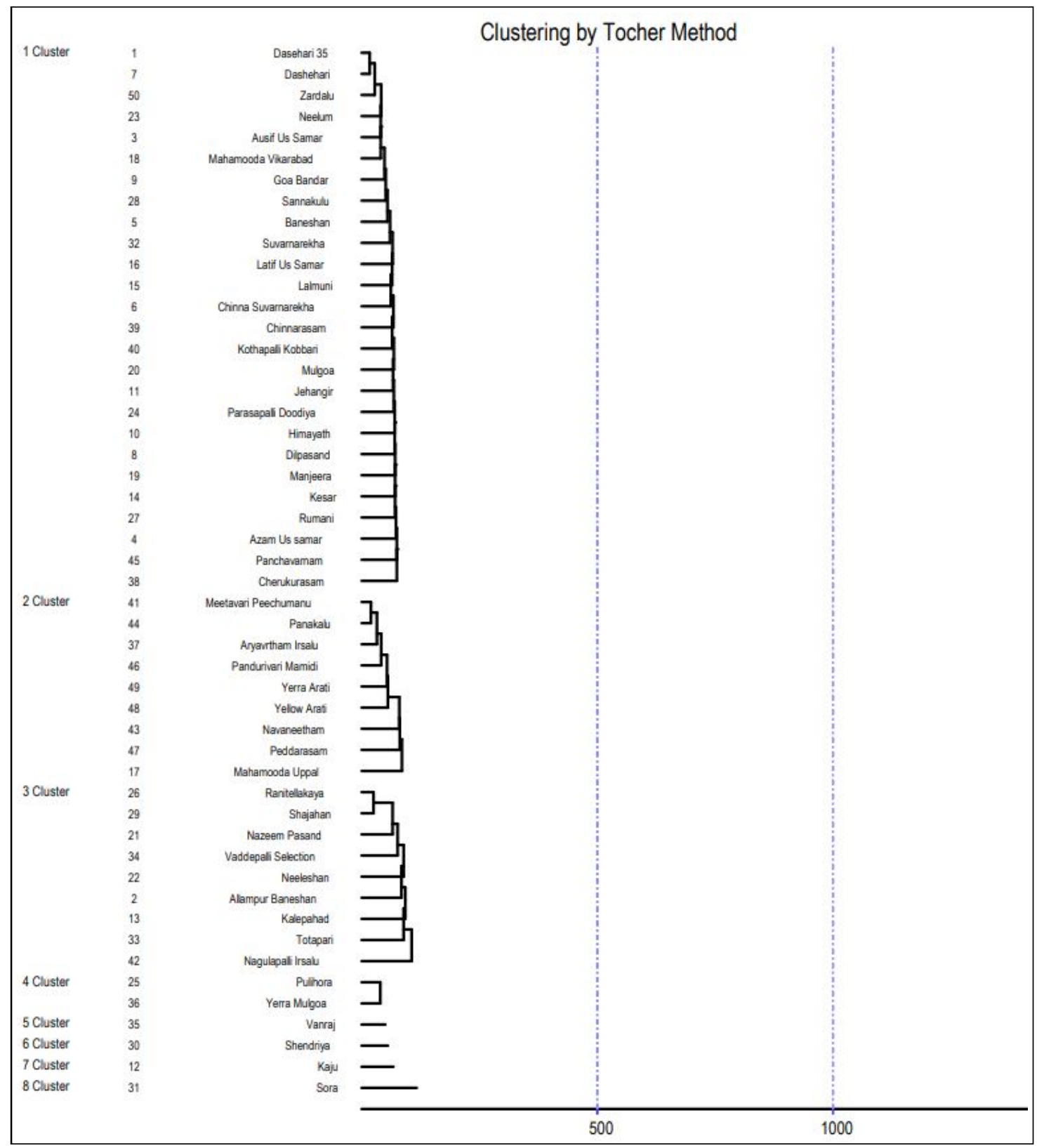

Fig 2: Dendrogram showing clustering pattern of 50 mango genotypes. 
$100 \mathrm{~g}$ ). The fifth component was showed $5.52 \%$ of the total variation and was correlated with pulp per cent, TSS (p Brix). Sixth component was accounted $5.31 \%$ variation and associated with TSS ( $p$ Brix), total phenolics content (mg of $\mathrm{GA} / 100 \mathrm{~g}$ ), total flavonoid content (mg QE/100g) and antioxidant activity $(\mu \mathrm{g} / 100 \mathrm{~g})$ and fibre content $(\mathrm{g} / 100 \mathrm{~g})$. Seventh principal component was explained $4.27 \%$ of total variation and correlated with vitamin $C$ content $(\mathrm{mg} / 100 \mathrm{~g})$ and total phenolics content ( $\mathrm{mg}$ of $\mathrm{GA} / 100 \mathrm{~g}$ ). The eighth principal component was accounted $3.78 \%$ of total variation and associated with fruit width $(\mathrm{cm})$, reducing sugars (\%) and total phenolics content (mg of GA/100 g).

However, the first two principal components for fifty cultivars were showed maximum variation and widely distributed along the axis which also showed in Fig 1. The similar results were also noticed by Krishnapillai and Wijeratnam (2016) and Majumdar et al. (2013), Tewodros Bezu Neguse et al. (2018) and Himabindu et al. (2017) in mango. Hence, it is indicating that, to give emphasis on traits which had a significant contribution to the observed variation for future breeding program.

The fifty mango cultivars were grouped into eight clusters by using $\mathrm{D}^{2}$ analysis was illustrated in Table 2 Fig 2. The results showed that cluster I comprising of 26 genotypes followed by cluster II and cluster III each with nine cultivars. Cluster 4 consisting of two cultivars viz., Pulihora and Yerra Mulgoa. Cluster V, VI, VII and VIII uniform clusters (Vanraj,
Shendriya, Kaju and Sora respectively). All popular table cultivars except Zardalu, Chinnarasam, Kothapalli Kobbarii, Panchavarnam and Cherukurasam were grouped in cluster I. Almost all juicy cultivars except Mahamooda Uppal were formed as single group (cluster II). Large sized table cultivars except one juicy cultivar (Nagulapalli Iraslu) formed as cluster III. Genotypes with high fruit weight can be utilized in crossing programme to realize broad spectrum of the genetic variability in segregating generations to affect the selection for fruit weight improvement. This clustering pattern clearly reflects the presence of considerable extent of genetic diversity among the genotypes under study. Similar results in relation to formation of large sized table cultivars in a cluster were reposted by Kumar et al. (2006); Rathod (2007) and Raina et al. (2015), Himabindu et al. (2015) in mango.

Dinesh et al. (2015) attempted to study the genetic diversity in some indigenous mango varieties of seedling origin and carried out evaluation of morphological traits in the Chittoor area of Andhra Pradesh in India.

The average intra and inter cluster distances for fifty genotypes are furnished in the Table 3 . Inter cluster distance ranged from 218.93 between cluster $\mathrm{V}$ and VII to 1475.21 between cluster IV and VIII and it was maximum between cluster IV and VIII (1475.21) followed by clusters VI and VIII (1269.55) and clusters VII and VIII. Cluster VIII showed maximum inter cluster distance with other clusters indicating wide genetic diversity between the genotypes. Selection of

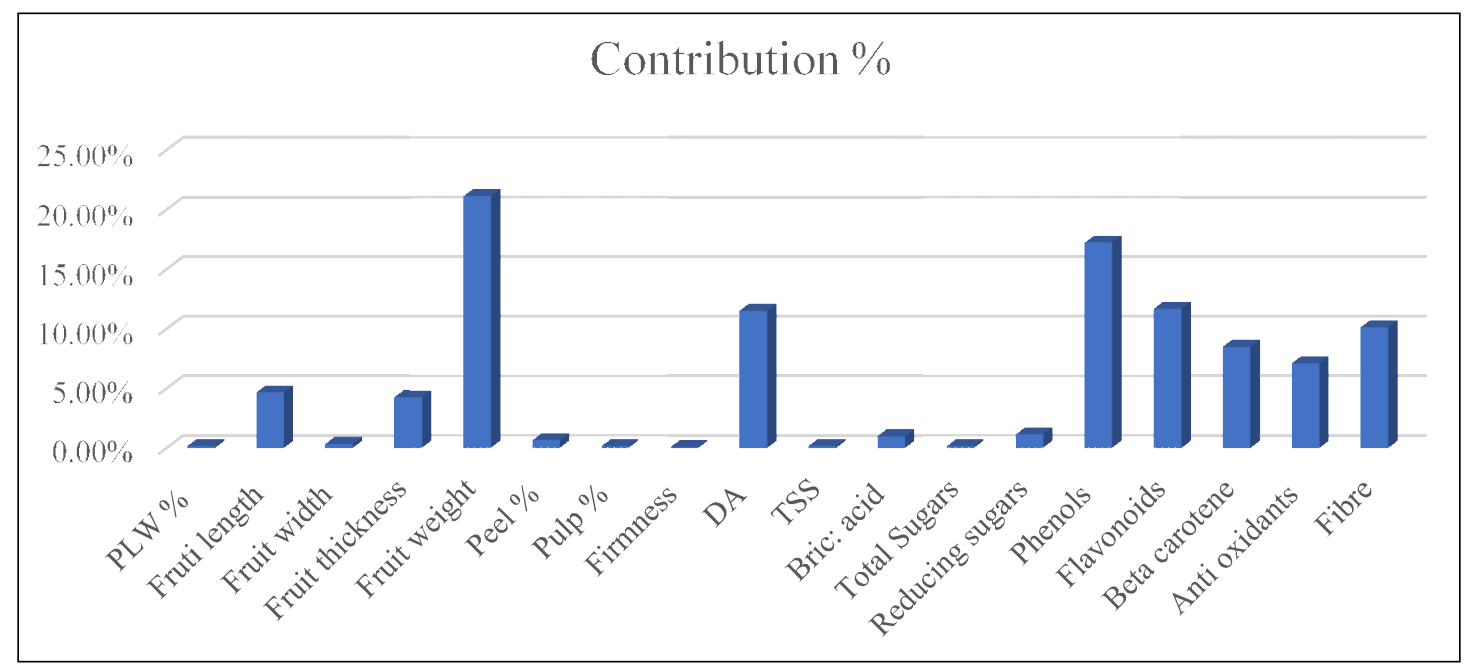

Fig 3: Per cent contribution of different characters of 50 mango genotypes to total genetic diversity.

Table 3: Average intra and inter cluster distances of 50 mango genotypes.

\begin{tabular}{|c|c|c|c|c|c|c|c|c|}
\hline & I & II & III & IV & V & VI & VII & VIII \\
\hline I & 189.56 & 304.53 & 392.36 & 362.92 & 276.05 & 268.23 & 285.90 & 939.76 \\
\hline II & & 212.22 & 390.12 & 597.28 & 412.14 & 324.52 & 351.74 & 1015.64 \\
\hline III & & & 280.69 & 680.00 & 357.81 & 516.64 & 407.63 & 569.51 \\
\hline IV & & & & 106.10 & 552.01 & 465.55 & 584.54 & 1475.21 \\
\hline V & & & & & 0.00 & 331.30 & 218.93 & 697.25 \\
\hline VI & & & & & & 0.00 & 302.01 & 1269.55 \\
\hline VII & & & & & & & 0.00 & 1136.69 \\
\hline VIII & & & & & & & & 0.00 \\
\hline
\end{tabular}


parents from such clusters for hybridization programme would help to evolve novel hybrids in mango. Intra cluster distance ranged from 0.00 in cluster $\mathrm{V}, \mathrm{VI}$, VII and VIII to 280.69 in cluster III. Cluster III contained 9 cultivars showing maximum intra cluster distance (280.69) thus, these cultivars were most heterogenous and followed by cluster II (212.22), cluster I (189.56) and cluster IV (106.10). Hence, genotypes from these clusters may be utilized in the hybridization programme to produce wide variability and transgressive segregants from diverse parents. Similar studies were conducted by Rajan et al. (2007) in guava; Rai and Misra (2005) in Bael, Kalia et al. (2001), Govanakoppa et al. (2002), Ramaprasad et al. (2006), Sharma et al. (2013) in apple, Barhate et al. (2012); Barholia and Sangeeta (2014); Indian et al. (2019), Himabindu et al. (2017), Shazia et al. (2017), Indian et al., (2019); Manchekar et al. (2011) and Rajan et al. (2009) in mango.

The genetic diversity was also corroborated with cluster means of fifty genotypes for different physico chemical traits under study revealed that considerable differences between the groups was given in table 4. From the present data, it is evident that cluster I was characterized with minimum fruit thickness (5.9), total sugars (8.88) and reducing sugars
(4.19). Cluster II was found to have genotypes with maximum mean values for DA reading (1.52), antioxidants (229.65) and fibre content (5.88) with minimum shelf life. The highest mean value for fruit width (9.08), fruit weight (460.03), pulp to stone ratio (5.12), brix acid ratio (56.05) with lowest mean value for peel per cent (13.88), stone per cent (12.39) and total phenols content (86.02) was observed in cluster III, indicating that genotypes having wide genetic base and desirable characters could be utilized in selection of parents in mango breeding. TSS, non-reducing sugars, flavonoids (19.59, 5.58 and 297.07) were recorded maximum under cluster IV. Cluster VI mixed up with desirable characters like TSS, total sugars, total phenols, antioxidants and flavonoids. The maximum mean value for physiological loss in weight (8.58), fruit length (12.11), fruit weight (770.64) pulp per cent (94.26), pulp to stone ratio (6.37), acidity (0.61) and minimum mean value for firmness (1.11), flavonoids (47.32) and beta carotene content (1.54) was found in cluster VIII.

The mean obtained for various characters from different genotypes in each cluster gives an idea about diversity among the clusters compared. It also helps to group the clusters according to their average performance. These results are in line with the reports of Manchekar et al. (2011),

Table 4: Cluster means for 25 post-harvest characters of 50 mango genotypes.

\begin{tabular}{|c|c|c|c|c|c|c|c|c|c|c|}
\hline Character & $\begin{array}{c}\text { Cluster } \\
1 \\
\end{array}$ & $\begin{array}{c}\text { Cluster } \\
2 \\
\end{array}$ & $\begin{array}{c}\text { Cluster } \\
3 \\
\end{array}$ & $\begin{array}{c}\text { Cluster } \\
4 \\
\end{array}$ & $\begin{array}{c}\text { Cluster } \\
5 \\
\end{array}$ & $\begin{array}{c}\text { Cluster } \\
6 \\
\end{array}$ & $\begin{array}{c}\text { Cluster } \\
7 \\
\end{array}$ & $\begin{array}{c}\text { Cluster } \\
8 \\
\end{array}$ & $\begin{array}{c}\text { Contribution } \\
\% \text { Time }\end{array}$ & $\begin{array}{c}\text { Ranked } \\
1^{\text {st }} \\
\end{array}$ \\
\hline PLW \% & 7.58 & 7.63 & 6.67 & 4.92 & 6.12 & 8.55 & 7.23 & 8.58 & $0.16 \%$ & 2 \\
\hline Firmness $\left(\mathrm{kg} / \mathrm{cm}^{2}\right)$ & 1.13 & 1.36 & 1.41 & 0.98 & 1.34 & 1.52 & 2.06 & 1.11 & $0.08 \%$ & 1 \\
\hline DA reading & 0.65 & 1.52 & 0.85 & 0.71 & 0.72 & 1.14 & 0.43 & 0.73 & $11.51 \%$ & 141 \\
\hline Fruit length $(\mathrm{cm})$ & 8.65 & 10.18 & 11.74 & 7.56 & 8.18 & 8.39 & 8.52 & 12.11 & $4.65 \%$ & 57 \\
\hline Fruit width $(\mathrm{cm})$ & 6.38 & 7.12 & 9.08 & 6.22 & 7.57 & 7.66 & 8.69 & 8.99 & $0.33 \%$ & 4 \\
\hline Fruit thickness $(\mathrm{cm})$ & 5.9 & 7.09 & 8.81 & 5.98 & 7.61 & 8.39 & 9.03 & 7.57 & $4.24 \%$ & 52 \\
\hline Fruit weight (grams) & 222.03 & 242.53 & 460.03 & 227.38 & 349.41 & 158.72 & 176.4 & 770.64 & $21.14 \%$ & 259 \\
\hline Peel per cent & 19.75 & 18.35 & 13.88 & 17.6 & 12.17 & 24.49 & 14.34 & 21.21 & $0.65 \%$ & 8 \\
\hline Pulp per cent & 61.06 & 53.4 & 57.06 & 57.87 & 59.66 & 56.14 & 47.2 & 94.26 & $0.16 \%$ & 2 \\
\hline Stone per cent & 20.41 & 22.45 & 12.39 & 16.01 & 13.52 & 22.95 & 19.85 & 14.89 &.$\%$ & 0 \\
\hline Pulp to peel ratio & 3.84 & 3.18 & 4.61 & 3.87 & 5.14 & 2.14 & 3.39 & 4.6 &.$\%$ & 0 \\
\hline Pulp to stone ratio & 3.26 & 2.48 & 5.12 & 4.57 & 4.08 & 2.21 & 2.47 & 6.37 &.$\%$ & 0 \\
\hline Shelf life (Days) & 5.72 & 5.3 & 6.04 & 5.67 & 7.33 & 5.67 & 6.5 & 5.33 &.$\%$ & 0 \\
\hline TSS ('Brix) & 18.6 & 17 & 17.32 & 19.59 & 12.75 & 19.92 & 16.96 & 16.03 & $0.16 \%$ & 2 \\
\hline Acidity (\%) & 0.46 & 0.4 & 0.35 & 0.43 & 0.36 & 0.55 & 0.25 & 0.61 &.$\%$ & 0 \\
\hline Vitamin C $(\mathrm{mg} / 100 \mathrm{~g})$ & 25.6 & 24.48 & 26.81 & 25.39 & 27.28 & 29.52 & 19.74 & 27.16 &.$\%$ & 0 \\
\hline Brix: acid ratio & 43.9 & 48.36 & 56.05 & 45.55 & 36.97 & 35.46 & 65 & 25.65 & $0.98 \%$ & 12 \\
\hline Total sugars (\%) & 8.88 & 9.21 & 9.29 & 9.63 & 9.68 & 9.82 & 8.98 & 9.39 & $0.16 \%$ & 2 \\
\hline Reducing sugars (\%) & 4.19 & 4.3 & 4.66 & 4.12 & 4.6 & 4.64 & 4.79 & 4.33 & $1.14 \%$ & 14 \\
\hline Non reducing sugars (\%) & 4.73 & 4.94 & 4.67 & 5.58 & 5.25 & 5.19 & 4.19 & 5.14 &.$\%$ & 0 \\
\hline $\begin{array}{l}\text { Total phenols content } \\
\text { (mg of GA/100g) }\end{array}$ & 111.03 & 90.3 & 86.1 & 134.61 & 89.49 & 164.73 & 80.03 & 80.8 & $17.22 \%$ & 211 \\
\hline $\begin{array}{l}\text { Total flavonoid content } \\
\text { (mg QE/100g) }\end{array}$ & 135.49 & 82.78 & 85.02 & 297.07 & 50.56 & 101.27 & 64.54 & 47.32 & $11.67 \%$ & 143 \\
\hline Beta carotene $(\mathrm{mg} / 100 \mathrm{~g})$ & 1.97 & 1.64 & 1.65 & 2.34 & 2.58 & 2.41 & 1.85 & 1.54 & $8.49 \%$ & 104 \\
\hline $\begin{array}{l}\text { Antioxidants activity } \\
(\mu \mathrm{g} / 100 \mathrm{~g})\end{array}$ & 220.6 & 229.65 & 220.57 & 222.02 & 216.31 & 232.13 & 191.66 & 181.73 & $7.10 \%$ & 87 \\
\hline Fibre content $(\mathrm{g} / 100 \mathrm{~g})$ & 4.68 & 5.88 & 4.93 & 4.34 & 3.41 & 5.79 & 3.22 & 4.12 & $10.12 \%$ & 124 \\
\hline
\end{tabular}


Shazia et al. (2017), Majumdar et al. (2013), Himabindu et al. (2017), Rajan et al. (2009), Sandra et al. (2013), Barholia and Sangeetha (2014), Rathod (2007), Indian et al. (2019) in mango; Ismail (2008) in case of lemon.

It is very essential to know the characters whose contribution is the most for the total genetic diversity so as to improve that character in the further breeding programs. It was observed from the percent contribution data (Table 4 and Fig 3), among physical traits fruit weight (g) ranked first with a maximum contribution towards genetic divergence of 21.14 per cent followed by DA reading $(11.51 \%)$, fruit thickness $(4.24 \%)$, fruit length $(4.65 \%)$. Characters such as stone per cent, pulp to peel ratio, pulp to stone ratio, shelf life had no contribution towards total divergence. Among the chemical traits total phenols content (17.22\%), flavonoids $(11.67 \%)$, fibre content $(10.12 \%)$, beta carotene content $(8.49 \%)$ antioxidants $(7.10 \%)$, reducing sugars $(1.14 \%)$, brix acid ratio $(0.98 \%)$, total sugars $(0.16 \%)$ contributed towards the genetic diversity in decreasing order. Acidity, vitamin C and non reducing sugars did not contributed towards diversity.

The experimental results further revealed that the mango genotypes selected for the present study are most divergent for total phenolics content, total flavonoid content, DA reading, fibre content, beta carotene content, antioxidants. Therefore, these characters should be given greater importance for the improvement of quality in further selection of segregants and choice of parents during hybridization programmes in mango. Similar studies were also carried out by Singh (2005), Rajan et al. (2009), Rufifni et al. (2011), Barhate et al. (2012), Majumder et al. (2013), Barholia and Sangeetha (2014) and Sandra et al. (2013) in mango; Clemilton et al. (2017) in papaya, and Singh et al. (2003) in pomegranate.

\section{CONCLUSION}

In the present investigation Fifty mango genotypes were grouped into eight distant clusters by performing Tocher's clustering method using Mahalanobis $D^{2}$ statistical analysis. Cluster I was the largest and comprised of 26 genotypes, cluster II and III each with 9 genotypes. Cluster IV with two cultivars and cluster V, VI, VII and VIII formed as solitary cluster. Inter cluster distance was maximum between cluster IV and VIII (1475.21). The cluster mean for most of the desirable characters was found in cluster II and III. Fruit weight contributed maximum towards genetic diversity followed by total phenolic content, total flavonoid content, DA reading, fibre content, beta carotene, antioxidants, fruit thickness and fruit length. Selection of genotypes from clusters that are far genetically and had the maximum association of physico chemical characters to obtain superior segregants in advanced generation to improve the quality of breeding in future.

\section{ACKNOWLEDGEMENT}

The authors thank the SKLTS Horticulture university, Rajendranagar for providing financial support and Fruit Research Station, Sangareddy for providing fruits and also
Institute of Biotechnology and Quality Control Laboratory (PJTSAU, Rajendranagar) for technical support.

\section{REFERENCES}

Arumuganathan, K. and Earle, E.D. (1991). Nuclear DNA content of some important plant species. Plant Mol Biol Rep. 9: 208-218. https://doi.org/10.1007/BF02672069.

Barhate, S.G., Balasubramanyan, S., Bhalerao, R.R., Bhalerao, P.P. (2012). Genetic diversity in mango (Mangifera indica L.) genotypic and phenotypic characterization. International Journal of Plant Science. (Muzaffarnagar). 8(1): 85-89.

Barholia, A.K. and Sangeeta, Y. (2014). Divergence for fruit characters in mango (Mangifera indica L.). African Journal of Agriculture Science and Technology. 2(2): 65-67.

Clemilton, A.S., Adriel, L.N., Jeferson, P.F., Omar. S., Renan, G.M., Rodrigo, S.A., Geraldo, A.F. and Edilson, R.S. (2017). Genetic diversity among papaya accessions. African Journal of Agricultural Research. 12(23): 2041-2048.

Dinesh, M.R., Ravishankar, K.V., Bhuwon Sthapit, Parthasarathy, V.A., Sandya, B.S., Nischita. P. and Lavanya, B. (2015). Genetic diversity studies in certain indigenous mango (Mangifera indica L.) varieties. Indian Journal of Plant Genetic Resources. 28(1): 153-160.

Govanakoppa, R.B., Hosmani, R.M. and Salimath, P.M. (2002). Genetic diversity in French bean under moisture stress condition. Vegetable Science. 29(1): 37-39.

Himabindu, A., Srihari, D., Rajasekhar, M., Sudhavani, V., Subbarammamma, P., Uma Krishna, K. and Paratpara, Rao, M. (2017). Genetic diversity for fruit morphological and biochemical characters of indigenous mango (Mangifera indica L.) cultivars of coastal districts in Andhra Pradesh using principal component analysis. Electronic Journal of Plant Breeding. 8(3): 772-778.

Indian, G R., Sankaranarayanan, S., Murugesan and Rajangam J. (2019). Assessment of genetic divergence using Mahalanobis $\mathrm{D}^{2}$ analysis in mango. Journal of Agriculture and Ecology. 7: $38-46$

Ismail, K.M. (2008). Genetic diversity and molecular characterization of lemon. Ph D Dissertation. Dept. of Horticulture, Bangladesh Agricultural University, Mymensingh. 233 P.

Kalia, N.R., Lal, M. and Kalia, R. (2001). Genetic divergence in common bean (Phaseolus vulgaris L.). Indian Journal of Agricultural Research. 35(2): 139-140.

Krishnapillai, N. and Wijeratnam, R.S.W. (2016). Morphometric analysis of mango varieties in Sri Lanka. Australian Journal of Crop Science. 10(6): 784-792.

Kumar, T., Joseph, P. and Johnkutty, I. (2006). Variability for physicochemical characteristics of mango genotypes in northern Kerala. Journal of Tropical Agriculture. 44(1-2): 57-60.

Mahalanobis, P.C. (1936). On the generalized distance in statistics. Proceeding of National Institute Science, India. 12: 49- 55.

Majumdar, D., Hassan, L.R. and Ma, M.K. (2013). Genetic Diversity In Mango (Mangifera Indica L.) Through Multivariate Analysis. Bangladesh Journal of Agricultural Research. 38(2): 343-353.

Manchekar, M.D., Mokashi, A.N., Hegde, R.V., Venugopal, C.K. and Byadgi, A.S. (2011). Clonal variability studies in alphonso mango (Mangifera indica L.) by genetic divergence $\left(\mathrm{D}^{2}\right)$ analysis. Karnataka Journal of Agricultural Sciences. 24(4): (490-492). 
National Horticulture Data Base. (2019-20). National Horticulture Board, Ministry of Agriculture, Government of India, Gurgoan, India.

Panse, V.G. and Sukhatme, P.V. (1989). Statistical Methods for Agricultural Workers. (Revised by: Sukhatme, P.V. and Amble, V.N.) ICAR Publication. New Delhi, pp. 100-109.

Rai, D. and Misra, K.K. (2005). Studies on genetic divergence in Bael (Aegle marmelos Correa). Indian Journal of Horticulture. 62: $152-54$.

Raina, D., Dhillon, Wasakhasingh Pps., Gill Singh. and Navprem. (2015). Assessment of genetic divergence using Mahalanobis $\mathrm{D}^{2}$ and principal component analysis of qualitative and quantitative characters in pomegranate genotypes under sub-tropics. Indian Journal of Horticulture. 72. 451.

Rajan, S., Yadava, L.P., Ram Kumar and Saxena, S.K. (2009). Genetic divergence in mango varieties and possible use in breeding. Indian Journal of Horticulture. 66(1): 7-12.

Rajan, S., Yadava, L.P., Kumar, R., Saxena, S.K. (2007). Genetic divergence in seed characteristics of guava: A basis for parent selection in hybridization. Indian Journal of Horticulture. 64(3): 290-293.

Ramaprasad, E., Rao, P.J.M., Kumar, P.V.R. and Rao, S.V. (2006). Study of genetic divergence in French bean (Phaseolus vulgaris L.). The Andhra Agriculture Journal. 56(3-4): 4-7.

Rao, C.R. (1952). Genetic Divergence. Methods and Analysis of Agriculture Crop. In: Advanced Statistical Method In Biometrical Research. John Wiley and Sons New York. pp. 357-362.

Rathod, B.P. (2007). Genetic variability, correlation, path coefficient and $\mathrm{D}^{2}$ analysis for morphological and biochemical parameters of mango fruit (Mangifera indica L.). Part of Ph.D. thesis submitted to the Navsari Agricultural University, Gujarat.

Rufini, J.C.M., Galvao, E.R., Lusinerio Prezotti., Marcelo Barreto Da Silva. and Rafael Augusto Da Costa Parrella. (2011). Biometrical and Physico-Chemical Characterization of fruits of Mango 'Ubá' accessions. Revista Brasileira, Frutic Jaboticaba. 33(2): 456-464.
Sandra, D.C.P., Adryellison Lemes de Campos., Nadsley Seraglio Souza., Leonarda Grillo Neves., Marco Antonio Aparecido Barelli., Petterson Baptista da Luz., Kelly Lana Araujo. and Severino de Paiva Sobrinho. (2013). Genetic Divergence in Mango and Obtaining Minimum Efficient Descriptors. American Journal of Plant Science. 4: 23182322.

Sharma, G., Sharma, N., Bashir, R., Khokhar, A. and Jamwal, M. (2013). Genetic divergence and cluster analysis studies of different apple genotypes using $D^{2}$ statistics. African Journal Agricultural Research. 8(37): 4681-4685.

Shazia, H., Bhat, K.M. and Rehman, H. U. (2017). Assessment of Genetic Variability of Wild Apple (Malus sp.) Genotypes in Kashmir Valley. International Journal of Plant and Soil Science. 14(5): 1-12.

Shirkhorshidi, A.S., Aghabozorgi, S. and Wah, T.Y. (2015). A Comparison Study on Similarity and Dissimilarity Measures in Clustering Continuous Data. PLOS ONE. 10(12): 1-20.

Singh, R., Meena, K.K. and Singh, S.K. (2003) Genetic divergence for yield and its component traits in pomegranate (Punica granatum L.). Indian Journal of Plant Genetic Resource. 16: 133-34.

Singh, R.C. (2005). Genetic characterization of mango (Mangifera indica L.) germplasm under north Indian conditions. Part of M.Sc. Thesis submitted to Indian Agricultural Research Institute, New Delhi.

Tewodros Bezu Neguse., Fredah K., Rimberia Wanzala., Wassu Mohammed Ali., Githiri Stephen Mwangi and Willis O. Owino. (2018). Phenotype characterization and diversity assessment of mango (Mangifera indica L.) cultivars in Ethiopia. Journal of Plant Breeding and Crop Science. 11(2): 55-67. 